\title{
LA DEVOCIÓN COMO FACTOR DE JERARQUIZACIÓN URBANA EN EL ARZOBISPADO DE TOLEDO (SS. XIV-XV). APUNTES PARA SU ESTUDIO*
}

\author{
DEVOTION AS A FACTOR OF URBAN HIERARCHY \\ IN THE ARCHBISHOPRIC OF TOLEDO (14 $4^{\text {th }}-15^{\text {th }}$ CENTURIES). \\ NOTES FOR ITS STUDY
}

\author{
MARIA JosÉ LOP OTÍN \\ Universidad de Castilla-La Mancha \\ http://orcid.org/0000-0002-2273-8618
}

\begin{abstract}
Resumen: El presente trabajo se centra en la faceta devocional de las seis principales ciudades del arzobispado de Toledo (Toledo, Talavera, Madrid, Guadalajara, Ciudad Real y Alcaraz) a finales de la Edad Media. Aspectos como la toponimia religiosa, el calendario festivo o el patronazgo de vírgenes y santos son analizados en un intento de señalar las relaciones jerárquicas entre esos núcleos de población y comparar sus respectivas realidades.

Palabras clave: Devoción; jerarquización urbana; arzobispado de Toledo; siglos XIV-XV; advocaciones; calendario festivo; patronazgo de vírgenes y santos.

Abstract: This paper focuses on the devotional features of the six leading cities in the Archbishopric of Toledo (Toledo, Talavera, Madrid, Guadalajara, Ciudad Real and Alcaraz) in the Late Middle Ages. Aspects such as religious place-names, the festive calendar, and the patronage of Virgins and saints are analysed in an attempt to identify the hierarchical relationships between these urban settlements and compare their respective realities.
\end{abstract}

Keywords: devotion; urban hierarchy; archbishopric of Toledo; $14^{\text {th }}-16^{\text {th }}$ centuries; dedications; festive calendar; patronage of virgins and saints.

\section{SUMARIO}

1. La devoción y sus significados.-2. El arzobispado de Toledo y sus ciudades.- 3. La toponimia religiosa y sus advocaciones.- 4 . El calendario festivo y las celebraciones.5. El patronazgo de vírgenes y santos.- 5.1. Las devociones marianas.- 5.2. Ildefonso e Isidoro: dos modelos de santidad para Toledo y Madrid.- 6. Reflexión final.7. Bibliografía citada.

"Este trabajo se ha realizado en el marco del Proyecto de Investigación "La Jerarquización urbana: villas y ciudades en Castilla (1400-1561)", financiado por el Ministerio de Economía y Competitividad (HARD2013-44014-P) y dirigido desde la Universidad Complutense de Madrid por la profesora María Asenjo González.

Cómo citar este artículo: Lop Otín, María José (2018), La devoción como factor de jerarquización urbana en el arzobispado de Toledo (ss. XIV-XV). Apuntes para su estudio, "Anuario de Estudios Medievales" 48/1, pp. 361-389. https://doi.org/10.3989/aem.2018.48.1.12

Copyright: (C) 2018 CSIC. Este es un artículo de acceso abierto distribuido bajo los términos de la licencia de uso y distribución Creative Commons Reconocimiento 4.0 Internacional (CC BY 4.0). 
Una de las más recientes formas de abordar el estudio de las ciudades bajomedievales y modernas se concreta en el concepto "jerarquización urbana”, procedente del ámbito de la geografía, que tiene por objeto conocer el comportamiento de dichas urbes en un marco de relaciones jerárquicas -a la par que recíprocas- de concurrencia, rivalidad y colaboración continuada. Esta vía de análisis permite evaluar el fenómeno urbano y las redes que se tejían en torno a él, esto es, la interacción entre las ciudades de más peso con las villas y enclaves rurales de su entorno, cuyo potencial, aun siendo de entrada menor, podría ser más pujante en aspectos de desarrollo específi$\mathrm{co}^{1}$. Entre los diversos campos de análisis que puede explorar esta renovada historia urbana -políticos, económicos, sociales, eclesiásticos, culturales- se encuentran el aspecto devocional, las expresiones de piedad y los sentimientos religiosos colectivos que desarrollaban sus habitantes. Pese al indudable interés del tema, esta vía de estudio comporta no pocas dificultades: de un lado, las derivadas de la novedad del planteamiento, que impide la existencia de propuestas metodológicas de base; de otro, el muy diferente conocimiento que en esta materia tenemos para el medio urbano medieval, pues junto a ciudades bien estudiadas, otras apenas si han esbozado la cuestión con unas breves notas. Esta disparidad de contenidos previos complica, como es lógico, el imprescindible análisis comparativo.

Justamente eso es lo que sucede en el caso que aquí me propongo ilustrar, el de las ciudades que integraban el arzobispado de Toledo a fines de la Edad Media, a las que ya he dedicado algún texto centrado en la presencia institucional de la Iglesia ${ }^{2}$. No ha sido una tarea fácil por las razones anteriormente expuestas y porque pronto comprendí que el objeto de estudio desbordaba con creces los límites de un trabajo como el que aquí se presenta. Es más, podría muy bien ajustarse a las condiciones de un proyecto de investigación de mayor calado, que, tras una recopilación bibliográfica exhaustiva, pasara a consultar fuentes primarias y pudiera así aportar un inventario completo de devociones y prácticas religiosas y, con él, una reflexión más profunda sobre la red de relaciones que vinculaban a unas ciudades con otras. Por ello, lo que presento aquí no es algo acabado, sino un primer acercamiento, que únicamente pretende mostrar una selección de las muchas posibilidades que ofrece el tema. Antes de ello, no obstante, es necesario precisar algunos conceptos.

${ }^{1}$ Stabel 2000.

${ }^{2}$ Lop 2014. 


\section{LA DEVOCIÓN Y SUS SIGNIFICADOS}

Tres son las cuestiones que conviene apuntar antes de abordar el estudio concreto de las devociones que se entretejían en las ciudades objeto de este análisis: las diversas acepciones del término, su relación con la liturgia, y el papel que desempeñan en la formación de identidades urbanas.

Hay que comenzar señalando que la devoción es un término complejo, que admite dos significados: el de dignidad, honestidad y buen orden en el culto, y el de piedad emotiva, adhesión o identificación amorosa con Dios, la Virgen y los santos ${ }^{3}$. Es decir, alude, por un lado, a la forma, unción y respeto con que el fiel cumple con el ritual y el culto que comportan los oficios litúrgicos; por otro, al lazo, al íntimo sentimiento y emotividad que esos mismos fieles establecen con algunas creencias. Tiene, por tanto, un componente que podríamos llamar externo y otro más íntimo e individual, si bien de lo que no se duda es de que tras ambos se esconde la creencia, la fe particular de cada persona: primero hay que conocer, hay que creer en algo para incorporarlo al mundo de los sentimientos personales en los que discurre la devoción ${ }^{4}$.

Una segunda cuestión que conviene apuntar es la relación existente entre devoción y liturgia, entendida ésta como el culto público regulado oficialmente por la Iglesia, que se concretaba en tres actos litúrgicos: la misa, las horas canónicas y los sacramentos. En ciertos casos se ha querido ver a ambos términos como antagónicos, partiendo de un planteamiento excesivamente simplista: la liturgia viene impuesta desde arriba por la jerarquía eclesiástica y no necesariamente movería a la devoción popular, y ésta y sus expresiones de piedad no son esenciales en el deber de los cristianos ni se encuadran entre los ritos ordenados por la Iglesia, por lo que, a veces, desbordan el marco institucional (catedralicio, parroquial) en que estos se desarrollan. Pretender que, a tenor de ello, liturgia y devoción han caminado separados no es hacer una lectura correcta de la cuestión. Más bien es todo lo contrario y así lo indica Raquel Torres:

no se trata de compartimentos estancos de la práctica y el sentimiento religiosos, ni tampoco cabe atribuir al clero el protagonismo excluyente en el primero, y al pueblo en el segundo: hay devociones que dan bien la medida de la religiosidad "popular", pero que son secundadas o dirigidas por clérigos con entusiasmo; hay celebraciones litúrgicas muy característicamente cultuales a las que el pueblo acude y otras en las que aporta sus modos de estar que terminan creando costumbre y por lo tanto, rito ${ }^{5}$.

${ }^{3}$ Torres 2002, p. 2.323 .

${ }^{4}$ Pérez 2005, pp. 37-38.

${ }^{5}$ Torres 2002, p. 557. 
Ambos campos, pues, aunque diferentes en su conceptualización, comparten idénticos escenarios, ya que buena parte de los actos devocionales que movían a los fieles se celebran en las mismas iglesias en las que se desarrolla la liturgia oficial de la Iglesia. Además, los cultos y creencias -por ejemplo, a determinados santos- que más devoción despertaban en el pueblo comportaban una parte litúrgica (los ritos que se desarrollan en el marco de la misa y el oficio canónico) y una parte devocional (vestir las imágenes, hacer romería, procesión o votos en honor de los santos). Es cierto que el campo devocional es el de la emotividad por excelencia, pero ésta también concurre en los actos litúrgicos.

Acaba este intento de desentrañar lo que comporta el término devoción apuntando el importante papel que ésta cumple en la definición o conformación de la identidad o las identidades locales, tema que hoy en día está en el punto de mira de tantos estudiosos ${ }^{6}$. En verdad, la presencia de la Iglesia en la ciudad contribuyó notablemente a desarrollar la conciencia y orgullo de sus habitantes. De entrada, éstos se identificaron con la monumentalidad de algunos de sus espacios sagrados, edificios que dominaban con su mayor altura el paisaje urbano del Occidente medieval y en los que descansaba una parte sustancial de la identidad urbana, pues eran signo visible de su prestigio cívico $^{7}$. Junto a esta presencia material, la conciencia ciudadana encuentra una vía de expresión preferente en un corpus de devociones y prácticas piadosas, construido a través del tiempo, que ayudó a proyectar y reafirmar la imagen de cada colectividad. Ese papel ha sido cohesivo y aglutinador muchas veces, pero excluyente y fuente de conflictos en otras, ya que la religiosidad ha reforzado también la conciencia de alteridad frente a todo lo que estaba más allá de la comunidad propia:

Es cierto que todos comparten una Iglesia católica, con sus sacramentos, su liturgia, su calendario de fiestas. Pero la religiosidad adquiere rasgos diferenciadores de identidad local. La Iglesia es una parroquia concreta. Cristo es interiorizado a partir de una imagen determinada, la devoción a la Virgen se manifiesta en veneración por la del Sagrario, la Esperanza o la Cabeza; el culto a los santos, en el apego a santa Ana, san Sebastián o san Gregorio ${ }^{8}$.

Algunos de los aspectos y valores sobre los que se sustentan esas señas de identidad y prácticas religiosas - procesiones, culto a los santos patronos, fiestas y celebraciones- fueron objeto de una apropiación por parte

\footnotetext{
${ }^{6}$ Interesantes reflexiones sobre el significado del término y las posibilidades que ofrece su estudio en Asenjo 2016; Barrio 2009-2010; Jara 2013; Montero 2012; Val Valdivieso 2006.

${ }^{7}$ Ladero 2010, p. 108.

${ }^{8}$ Martínez 2000, p. 19.
} 
diversos poderes -monarquía, nobleza, alto clero- en un intento claro de reforzar su legitimación ante el pueblo9. Entre ellos estaban las autoridades municipales y, si bien este aspecto quedará fuera del presente estudio, no puedo dejar de mencionar la expresión, "religión cívica" o "cristianismo cívico", que ha hecho fortuna en las últimas décadas y ampara todo ese universo de relaciones político-religiosas que se proyectaban en las ciudades del Occidente medieval ${ }^{10}$. Lo cierto es que esa religión cívica sería la expresión litúrgica y religiosa de un patriotismo local, y de la creencia común en el papel salvífico de la ciudad ${ }^{11}$. Los aspectos devocionales que aquí analizamos cumplen un papel de primer orden en estas manifestaciones cívicas colectivas, de ahí las múltiples conexiones que subyacen en todo ello.

\section{El ARZOBISPADO DE TOLEDO Y SUS CIUDADES}

Como dije al comienzo, el marco elegido para explorar el papel que las manifestaciones devocionales y las prácticas religiosas tuvieron a la hora de establecer una jerarquización o interacción urbana, es el del arzobispado de Toledo en el tránsito de la Edad Media a la Moderna, que en ningún caso era una más entre las casi cincuenta sedes episcopales que conformaban la red eclesiástica de los reinos hispanos. Por el contrario, estamos ante la más poderosa archidiócesis de la Península tanto en nivel de rentas como en prestigio e influencia. Así lo acreditaba su condición de sede primada, la enorme provincia eclesiástica de la que Toledo era metropolitana, y la vasta archidiócesis que debían administrar sus prelados, que para su mejor administración se dividía en seis arcedianatos -Toledo, Talavera, Madrid, Guadalajara, Calatrava y Alcaraz-, veintitrés arciprestazgos y tres vicarías.

Las ciudades elegidas para centrar el estudio son, precisamente, las seis que constituyen la cabeza de cada uno de esos arcedianatos, fuera de las cuales la cara que presentaba el arzobispado era muy rural, en continuidad con la dispersión urbana que ya había caracterizado a estas tierras desde época islámica ${ }^{12}$. En todo caso, estamos ante núcleos con una entidad bastante desigual: Toledo, con unos 25.000 o 30.000 habitantes a fines del siglo XV, sí respondía al modelo

${ }^{9}$ Las relaciones entre poder y devoción han sido abordadas recientemente para el ámbito castellano en Beceiro 2014.

${ }^{10}$ Muchos son los trabajos que han explorado esta fórmula trasladándola a diversos contextos. Sirvan como ejemplo los reunidos en Vauchez 1995 y el dosier dedicado al tema en la revista Histoire urbaine 27 (2010).

${ }^{11}$ Lóbrichon 1994, p. 136.

${ }^{12}$ Izquierdo 2006. 
de ciudad grande, mientras que el resto son villas de rango medio, que oscilaban entre los 4.000 a 8.000 habitantes y que nunca se desligaron plenamente del entorno rural y agrícola que les rodeaba ${ }^{13}$. Todas eran ciudades de realengo, salvo Talavera, que en 1369 fue transferida por Enrique II a la mitra toledana, y ejercían jurisdicción sobre extensos alfoces, menos Villa Real -Ciudad Real desde 1420-, que no podía crecer al estar rodeada por los dominios calatravos. Cinco de ellas, la excepción esta vez es Alcaraz, tuvieron representación en Cortes y todas fueron favorecidas con la celebración de ferias y reuniones mercantiles que contribuyeron a dinamizar su vida económica y la de su entorno.

Sus diferencias se proyectaban también en lo eclesiástico, pues su equipamiento religioso estaba, como luego veremos, muy desigualmente repartido. Lo mismo sucedía con la dotación beneficial, claramente decantada a favor de Toledo que reunía ciento once beneficios parroquiales -curados, servideros y prestameros- lejos de los cincuenta y siete de Talavera, los cuarenta y cinco de Madrid, los treinta y tres de Guadalajara y, aún más, de los veinte de Ciudad Real y Alcaraz ${ }^{14}$. La posibilidad de conocer estos datos nos la brinda un interesante documento de 1501, el Libro de Beneficios del Arzobispado de Toledo, realizado a instancias del cardenal Cisneros que permite comparar por primera vez la realidad beneficial de todas las poblaciones de la sede toledana en un mismo estadio cronológico ${ }^{15}$.

Ahora bien, más allá de lo institucional y beneficial, ¿qué sucedía en el plano devocional?, ¿también eran tantas las diferencias entre las creencias y devociones de nuestras ciudades?, ¿eran similares las formas de expresión religiosa laica, las prácticas de fe?, ¿había rivalidad intra e interurbana? Estamos ante preguntas muy interesantes y reveladoras del funcionamiento de un sistema social bien asentado, a las que van destinadas las siguientes líneas. Parto para ello de una variada bibliografía, que citaré oportunamente, y que puede calificarse de desigual, dado que incluye desde tesis doctorales y monografías con una buena base documental e interpretativa a trabajos muy puntuales y casi anecdóticos, que rozan lo folclórico o la militancia confesional y que recogen ideas de la tradición sin aplicarles el tratamiento crítico deseable. A ello se suma la dispar distribución geográfica de tales investigaciones, pues no todas las ciudades han merecido la misma atención de los estudiosos ni cuentan, por tanto, con igual número de publicaciones sobre el tema. Esa compartimentación no ha favorecido la realización de obras de conjunto, ni mucho menos los intentos de síntesis y análisis comparativos.

\footnotetext{
${ }^{13}$ Asenjo 2003; Igual 2002; Ladero 2010, pp. 30-32.

${ }^{14}$ Lop 2014.

${ }^{15}$ Torres 2006a.
} 
Pese a todo, hay trabajos que, aunque centrados mayormente en el ámbito rural castellano y en un periodo cronológico posterior, ayudan como punto de partida. Es el caso de las clásicas obras de William A. Christian ${ }^{16}$ y Francisco Javier Campos ${ }^{17}$ elaboradas a partir de la información aportada por las Relaciones Topográficas de Felipe II. De gran utilidad han sido los trabajos de Raquel Torres, que ponen el foco en un amplio territorio del arzobispado de Toledo, el Campo de Calatrava. Más allá de las posibilidades que ofrece para comparar las prácticas piadosas de los pueblos sometidos a la jurisdicción calatrava con las seis ciudades mencionadas, sus trabajos aportan la definición conceptual y la base metodológica precisa para abordar esta línea de análisis ${ }^{18}$. Finalmente, hay que mencionar, por la interesante información que aportan, la publicación de los sínodos y concilios toledanos que en su día hizo José Sánchez Herrero ${ }^{19}$, reuniones que han sido objeto recientemente de una nueva edición ${ }^{20}$. Fuera de aquí, hay mucho por hacer, de ahí que nos encontremos con un terreno completamente abierto, en claro contraste con el interés que estos aspectos han suscitado en otras diócesis como las andaluzas y castellano-leonesas ${ }^{21}$ o el vecino obispado de Cuenca ${ }^{22}$.

Para este primer acercamiento al tema he partido de tres indicadores que creo que pueden resultar reveladores de la cuestión: la toponimia religiosa y sus advocaciones, el calendario festivo y sus celebraciones, y el patronazgo de vírgenes y santos. Quedan fuera otros aspectos, que se podrán abordar más adelante, pues exceden los límites de este trabajo, caso del estudio de las cofradías, las donaciones pro anima y mandas testamentarias, la devoción ligada a la muerte y a sus rituales funerarios, las imágenes, altares y representaciones iconográficas que albergan las iglesias, o los libros devocionales de las bibliotecas parroquiales.

\section{LA TOPONIMIA RELIGIOSA Y SUS ADVOCACIONES}

La toponimia de la ciudad es mayoritariamente religiosa: templos y conventos son puntos de referencia o dan nombre a plazas, campos, compases, gradas. Las puertas de la muralla portan hornacinas y, a veces, nombres eclesiásticos; hay, además,

\footnotetext{
${ }^{16}$ Christian 1991.

${ }^{17}$ Campos 1986.

${ }^{18}$ Torres 2002, 2006b, 2013, 2016-2017.

${ }^{19}$ Sánchez 1976.

${ }^{20}$ García 2011,pp. 519-829.

${ }^{21}$ Sánchez 1978, 1982.

${ }^{22}$ Díaz 2002.
} 
ermitas y humilladeros urbanos. Los hombres viven, en suma, bañados por una nomenclatura religiosa desde que aprenden a andar por las calles de su ciudad (...). En los monumentos y topónimos religiosos descansaba una parte sustancial de la identidad urbana. Los nexos que esto creaba entre ciudad e Iglesia eran fortísimos, porque atañían a aspectos que nacían en la vida cotidiana para penetrar directamente en la conciencia colectiva $^{23}$.

Poco más puede añadirse a estas palabras, que justifican plenamente el siguiente repaso por las advocaciones de las iglesias principales de nuestras seis ciudades. Su realidad nos es bien conocida, amén de por la variada bibliografía que las estudia con mayor o menor detalle ${ }^{24}$, por el citado Libro de Beneficios de 1501. En esa fecha, y en clara continuidad con toda la etapa bajomedieval, estamos hablando de una catedral, tres colegiatas (dos en Toledo y otra en Talavera $)^{25}$ y sesenta y seis parroquias, de las cuales veintisiete se localizan en Toledo, trece en Madrid, nueve en Talavera y Guadalajara, cinco en Alcaraz y tres en Ciudad Real. Esos setenta edificios se identificaban con treinta y cinco advocaciones, que se pueden distribuir en las cuatro categorías que refleja el siguiente cuadro:

Tabla 1. Distribución de las advocaciones

\begin{tabular}{|l|c|c|c|c|c|c|c|}
\hline CATEGORÍAS & TO (30) & MA (13) & TA (10) & GU (9) & AL (5) & CR (3) & TOTAL \\
\hline Dios (3) & 1 & 2 & 1 & & 1 & & 5 \\
\hline Virgen (1) & 1 & 1 & 1 & 1 & 1 & 1 & 6 \\
\hline Santas (4) & 6 & & 1 & & & & 7 \\
\hline Santos (27) & 22 & 10 & 7 & 8 & 3 & 2 & 52 \\
\hline
\end{tabular}

La primera de esas categorías se refiere a la devoción a Dios, que, a su vez, admite varias vertientes: como Creador, Jesucristo, Trinidad o Espíritu Santo. En nuestras ciudades sólo hay tres advocaciones en cinco parroquias: San Salvador en Toledo, Madrid y Talavera; la Trinidad en Alcaraz; y Santa Cruz en Madrid. Tal vez son tan pocos porque, como indica Raquel Torres, su papel nuclear y permanente en la religiosidad no requiere más dedicación. No era nece-

\footnotetext{
${ }^{23}$ Ladero, Sánchez 1991.

${ }^{24}$ Andrés de 1986; Arganda 2001; Ayllón 2010, 2015; Gonzálvez 1978; Layna 1942; Lop 2003, 2012, 2014; Muñoz 1993, 2002; Pretel 2000; Villegas 1981.

${ }^{25}$ En la archidiócesis había otras dos colegiatas, pero no estaban en las seis ciudades señaladas. Es el caso de la abadía de San Vicente de la Sierra, fundada hacia 1156 y ubicada en el término de Hinojosa de San Vicente, y la de los Santos Justo y Pastor en Alcalá de Henares, constituida en 1477 a petición del arzobispo Alonso Carrillo.
} 
sario enfatizar con distintas advocaciones una presencia de la divinidad que, de por sí, era continua en la liturgia y en los principios esenciales de la propia $\mathrm{fe}^{26}$.

Mayor presencia tenían los intercesores antes esa divinidad, Virgen y santos, a los que va dedicada la práctica totalidad de los templos. En ese sentido, sobresale la dedicación mariana, pues cada ciudad mantuvo un templo intitulado "de Santa María", al que Madrid añade el topónimo "de la Almudena", en recuerdo del lugar donde apareció la imagen en 1085, una zona del recinto fortificado o al-mudayna. En todos los casos se trata de iglesias principales de cada una de esas ciudades: la catedral en Toledo, la colegiata de Talavera, y la parroquia mejor dotada beneficialmente de Madrid, Guadalajara, Alcaraz y Ciudad Real ${ }^{27}$.

En la categoría "santas", solo aparecen cuatro: las mártires hispanas, Leocadia, Eulalia, y Justa y Rufina, a las que se suma una devoción francesa, María Magdalena. Todas son titulares de una parroquia en Toledo, pero el caso a destacar es el de Leocadia, que en esta ciudad tuvo también una abadía extramuros y una capilla, localizada en el recinto militar del Alcázar, amén de una parroquia en Talavera. Está claro que se trata de una devoción local, ligada a estas tierras toledanas, frente a la emeritense Eulalia y a las sevillanas Justa y Rufina, devociones que seguramente trajeron consigo los mozárabes que en el siglo XII huyeron de la persecución almohade y se asentaron en la ciudad del Tajo ${ }^{28}$.

Sin duda, el grupo más grande es el de los veintisiete santos titulares de cincuenta y dos parroquias en nuestras ciudades, entre los que hay un variado elenco. El más representado es el arcángel san Miguel, con seis edificios en todas las ciudades, excepto en Ciudad Real, y que en Madrid tuvo incluso dos parroquias (de los Octoes y de la Sagra). Le siguen los apóstoles Pedro y Santiago, que cuentan con una parroquia por ciudad a excepción en el primer caso de Guadalajara y en el segundo de Alcaraz. El también apóstol san Andrés y el mártir Ginés de Arlés ostentan la titularidad de cuatro parroquias, una más que las acogidas bajo la advocación de los obispos Martín de Tours y Nicolás de Bari. Otro apóstol, santo Tomé, y los mártires Justo y Pastor son titulares de dos templos, quedando el resto de nombres al frente de una sola parroquia. Entre ellos hay más apóstoles (Bartolomé, Juan), mártires hispánicos (Vicente, Torcuato) y foráneos (Sebastián, Cipriano, Juan Bautista, Román, Cristóbal, Esteban, Lorenzo), evangelistas (Marcos y Lucas), obispos (Isidoro de Sevilla, Clemente, Ignacio de Antioquía) y un abad (san Gil).

\footnotetext{
${ }^{26}$ Torres 2002, p. 2.328.

${ }^{27}$ Lop 2014, pp. 144-146.

${ }^{28}$ La tradición, que ya recogió en su día el padre Flórez, dice que la parroquia se asentó sobre la vivienda de Leocadia, la capilla sobre la prisión donde murió y la basílica extramuros sobre su sepulcro. Izquierdo 2016, pp. 56-57.
} 
Tabla 2. Relación de advocaciones

\begin{tabular}{|l|c|c|c|c|c|c|c|}
\hline ADVOCACIÓN & TO (29) & MA (13) & TA (10) & GU (9) & AL (5) & CR (3) & TOTAL \\
\hline San Salvador & $\mathrm{X}$ & $\mathrm{X}$ & $\mathrm{X}$ & & & & 3 \\
\hline La Trinidad & & & & & $\mathrm{X}$ & & 1 \\
\hline Santa Cruz & & $\mathrm{X}$ & & & & & 1 \\
\hline Santa María & $\mathrm{X}$ & $\mathrm{X}$ & $\mathrm{X}$ & $\mathrm{X}$ & $\mathrm{X}$ & $\mathrm{X}$ & 6 \\
\hline Santa Eulalia & $\mathrm{X}$ & & & & & & 1 \\
\hline Santa Justa & $\mathrm{X}$ & & & & & & 1 \\
\hline Santa Leocadia & $\mathrm{XXX}$ & & $\mathrm{X}$ & & & & 4 \\
\hline Santa María & $\mathrm{X}$ & & & & & & 1 \\
Magdalena & & & & & & & \\
\hline San Justo & $\mathrm{X}$ & $\mathrm{X}$ & & & & & 2 \\
\hline San Isidoro & $\mathrm{X}$ & & & & & & 1 \\
\hline San Nicolás & $\mathrm{X}$ & $\mathrm{X}$ & & $\mathrm{X}$ & & & 3 \\
\hline San Román & $\mathrm{X}$ & & & & & & 1 \\
\hline San Marcos & $\mathrm{X}$ & & & & & & 1 \\
\hline San Sebastián & $\mathrm{X}$ & & & & & & 1 \\
\hline San Andrés & $\mathrm{X}$ & $\mathrm{X}$ & $\mathrm{X}$ & $\mathrm{X}$ & & & 4 \\
\hline San Cebrián & $\mathrm{X}$ & & & & & & 1 \\
\hline San Torcuato & $\mathrm{X}$ & & & & & & 1 \\
\hline San Cristóbal & $\mathrm{X}$ & & & & & & 1 \\
\hline San Bartolomé & $\mathrm{X}$ & & & & & & 1 \\
\hline San Antolín & $\mathrm{X}$ & & & & & & 1 \\
\hline Santo Tomé & $\mathrm{X}$ & & & $\mathrm{X}$ & & & 2 \\
\hline San Lucas & $\mathrm{X}$ & & & & & & 1 \\
\hline San Ginés & $\mathrm{X}$ & $\mathrm{X}$ & $\mathrm{X}$ & $\mathrm{X}$ & & & 4 \\
\hline San Lorenzo & $\mathrm{X}$ & & & & & & 1 \\
\hline San Miguel & $\mathrm{X}$ & $\mathrm{XX}$ & $\mathrm{X}$ & $\mathrm{X}$ & $\mathrm{X}$ & & 6 \\
\hline San Vicente & $\mathrm{X}$ & & & & & & 1 \\
\hline San Juan Bautista & $\mathrm{X}$ & & & & & & 1 \\
\hline Santiago & $\mathrm{X}$ & $\mathrm{X}$ & $\mathrm{X}$ & $\mathrm{X}$ & & $\mathrm{X}$ & 5 \\
\hline San Martín & $\mathrm{X}$ & $\mathrm{X}$ & $\mathrm{X}$ & & & & 3 \\
\hline San Pedro & $\mathrm{X}$ & $\mathrm{X}$ & $\mathrm{X}$ & & $\mathrm{X}$ & $\mathrm{X}$ & 5 \\
\hline San Juan apóstol & & $\mathrm{X}$ & & & & & 1 \\
\hline San Clemente & & & $\mathrm{X}$ & & & & 1 \\
\hline San Esteban & & & & $\mathrm{X}$ & & & 1 \\
\hline San Gil & & & $\mathrm{X}$ & & & 1 \\
\hline San Ignacio de \\
Antioquía & & & & $\mathrm{X}$ & & 1 \\
\hline
\end{tabular}


Resumiendo, las advocaciones a santos representan un $74,2 \%$, quedando la de santas $(10 \%)$, Virgen $(8,5 \%)$ y Dios $(7,1)$ muy por debajo de ellas. Como es natural más allá de la ordenación y cuantificación de estas dedicaciones parroquiales interesa ver el porqué de los cultos y las razones de su elección. Lamentablemente, al ser la que analizamos una etapa tardía respecto al momento en que casi todos los templos fueron erigidos (siglos XII y XIII), no podemos establecer una relación tan directa entre sus titulares y los fieles que acudían a ellos en demanda de diferentes servicios religiosos. Es difícil saber si la advocación fue impuesta desde arriba, por la Iglesia oficial, o si fue propiciada de forma más espontánea por la demanda popular. En todo caso, sí pueden ser un indicador de la fuerte identificación de los fieles con el barrio en que vivían, al que daba nombre la parroquia asentada en el mismo. Lo que también se comprueba es que responden a unas secuencias tipológicas muy comunes en toda la zona castellana y, en general, a las redes parroquiales medievales ${ }^{29}$. Se impone la figura mariana en, al menos, una iglesia de cada ciudad, y hay una distribución equilibrada entre santos de diferente procedencia y condición. Eso sí, en ningún caso entre estas dedicaciones está presente el modelo monástico que, lógicamente se reserva para las fundaciones que las distintas órdenes harán en nuestras ciudades.

\section{EL CALENDARIO FESTIVO Y LAS CELEBRACIONES}

Otra de las vías por la que podemos rastrear las devociones populares tiene que ver con el amplio universo de las fiestas y celebraciones religiosas, "mirador privilegiado" en unión de otras -cívicas, políticas, familiares, transgresoras- para conocer la mentalidad colectiva y el orden cultural de la sociedad en que se desarrollaban ${ }^{30}$. Aunque eran las autoridades eclesiásticas las que disponían y regulaban ese calendario de fiestas, incorporándolas y acompasándolas a los distintos tiempos del año litúrgico, el conjunto de ritos, símbolos y actos que comportaban permitían al pueblo participar de ellas y expresar de diversas formas su devoción y sentimientos piadosos.

La Tabla de festividades diocesanas para el conjunto del arzobispado quedó fijada en diversas sinodales de los siglos XIV y XV, entre las que es referencia el Libro sinodal que en 1356 recopiló el arzobispo Blas Fernández de Toledo para poner al día todas las constituciones de sus antecesores. El prelado señaló cuarenta y tres fiestas de guardar por los fieles de

\footnotetext{
${ }^{29}$ Vauchez 1994.

${ }^{30}$ La bibliografía sobre el tema es amplísima. Remito como obra de referencia a Ladero 2004 y a los más recientes trabajos de Asenjo 2013 y Narbona 2017.
} 
la archidiócesis, a las que se sumarían los cincuenta y dos domingos, aunque alguno de ellos coincidiría con fiestas de la Tabla ${ }^{31}$. Podemos agruparlas en cuatro bloques:

- Las tres fiestas cristológicas relacionadas con las tres Pascuas: Natividad (con los tres días siguientes de San Esteban, San Juan y los Santos Inocentes), Resurrección y Pentecostés, ambas con los dos días siguientes.

- Fiestas relacionadas con momentos importantes de la vida y muerte de Jesucristo (Circuncisión, Triunfo de la Cruz, Transfiguración, Ascensión, Corpus Christi), y de la Virgen (Purificación, Anunciación, Asunción, Expectación).

- Fiestas de apóstoles (Cátedra de San Pedro, Matías, Felipe y Santiago, Bernabé, Pedro y Pablo, Santiago el Mayor, San Pedro ad Vincula, Bartolomé, Mateo, Simón y Judas, Andrés, Tomás, Juan), evangelistas (Marcos, Lucas, Juan), arcángeles (San Miguel), mártires (Juan Bautista, Lorenzo, Esteban, Santos Inocentes), obispos (San Nicolás), santos (Todos los Santos) y santas (Santa María Magdalena).

- Fiestas especialmente relacionadas con la ciudad y el arzobispado de Toledo (San Ildefonso y San Eugenio).

Algunos sínodos posteriores introdujeron nuevas celebraciones, diez en concreto, pero no todas eran de observancia por el pueblo. Así el sínodo diocesano de Alcalá convocado por Pedro Tenorio en 1379 estableció las de Santa María de las Nieves, San Gabriel y la de un difícil de identificar San Juonis $^{32}$. Un siglo después (1481), el sínodo que Alonso Carrillo reunió en esa misma ciudad estableció las de Santa Quiteria y Santa Úrsula ${ }^{33}$. Al acabar el siglo se establecieron cinco más, dispuestas por Cisneros en los sínodos de Alcalá (1497) y Talavera (1498) $)^{34}$. Fueron las de San Julián, San José, la Presentación de María en el Templo y las que sí se apuntan como de guardar por el pueblo, las de los dos fundadores mendicantes San Francisco y Santo Domingo.

El siguiente cuadro refleja la distribución de todas estas festividades en cada uno de los meses del año a fines de la Edad Media:

\footnotetext{
${ }^{31}$ Sánchez 1976, pp. 229-230; García (dir.) 2011,pp. 572-573.

${ }^{32}$ Sánchez 1976, p. 252; García (dir.) 2011, p. 599.

${ }^{33}$ Sánchez 1976, p. 337; García (dir.) 2011,pp. 674-675.

${ }^{34}$ Sánchez 1976, pp. 349 y 361; García (dir.) 2011, pp. 686 y 750.
} 
Tabla 3. Calendario litúrgico del arzobispado de Toledo (1498)

\begin{tabular}{|l|l|}
\hline ENERO & SEPTIEMBRE \\
\hline 1. Circuncisión del Señor & 8. Natividad de Santa María \\
\hline 6. Epifanía del Señor & 21. San Mateo Apóstol \\
\hline 23. San Ildefonso & 29. San Miguel Arcángel \\
\hline FEBRERO & OCTUBRE \\
\hline 2. Purificación de Santa María & 4. San Francisco de Asís \\
\hline 22. Cátedra de San Pedro & 18. San Lucas Evangelista \\
\hline 24. San Matías Apóstol & 21. Santa Úrsula y las Once Mil Vírgenes \\
\hline MARZO & 28. Santos Simón y Judas Apóstoles \\
\hline 6. San Julián & NovIEMBRE \\
\hline 19. San José & 1. Todos los Santos \\
\hline 24. San Gabriel Arcángel & 15. San Eugenio \\
\hline 25. Anunciación de Santa María & 20. Presentación de María en el Templo \\
\hline ABRIL & 30. San Andrés \\
\hline 25. San Marcos Evangelista & DICIEMBRE \\
\hline MAYO & 6. San Nicolás \\
\hline 1. Santos Felipe y Santiago Apóstoles & 18. Expectación de la Virgen \\
\hline 22. Santa Quiteria & 21. Santo Tomás Apóstol \\
\hline JUNIO & 25. Nacimiento del Señor \\
\hline 11. San Bernabé Apóstol & 26. San Esteban \\
\hline 24. Nacimiento de San Juan Bautista & 27. San Juan Apóstol y Evangelista \\
\hline 29. San Pedro y San Pablo Apóstoles & 28. Santos Inocentes \\
\hline JULIO & FIESTAS MóVILES \\
\hline 17. Triunfo de la Santa Cruz & Pascua de Resurrección del Señor (y 2 días ss.) \\
\hline 22. Santa María Magdalena & Ascensión del Señor \\
\hline 25. Santiago Apóstol & Pascua de Pentecostés (y 2 días ss.) \\
\hline AGOSTO & Corpus Christi \\
\hline 1. San Pedro ad Vincula & \\
\hline 4. Santo Domingo de Guzmán & \\
\hline 5. Santa María de las Nieves & \\
\hline 6. Transfiguración del Señor & \\
\hline 10. San Lorenzo & \\
\hline 15. Asunción de Santa María & \\
\hline 24. San Bartolomé Apóstol & \\
\hline
\end{tabular}

Si tenemos en cuenta que a estas casi cien festividades de la Tabla (domingos incluidos) se sumaban los días en que cada parroquia conmemoraba la solemnidad de su advocación, así como las fiestas civiles y las patronales 
de gremios y cofradías, se puede concluir que en torno a una tercera parte del año era, de un modo u otro, fiesta. Las autoridades, laicas y eclesiásticas, veían en el ocio un posible fomento de vicios, amén de un detrimento en la capacidad productiva por la paralización del trabajo ${ }^{35}$. Por ello los siglos finales de la Edad Media propiciaron una reducción de festividades, que al arzobispado de Toledo llegaría en el sínodo de 1336, convocado por su prelado Juan de Aragón $^{36}$ y tendría continuidad en el ya mencionado Libro sinodal de 1356.

Más allá de conocer numéricamente el conjunto de festividades diocesanas, cabe preguntarse por el grado de implicación, el sentimiento piadoso y la devoción que su conmemoración despertaba en el pueblo, aspectos todos ellos muy difíciles de desentrañar. Solo podemos servirnos de indicadores externos, como, por ejemplo, del cumplimiento o no por los fieles que vivían en nuestras ciudades de la obligación de descansar y oír los oficios divinos durante los domingos e fiestas que la iglesia guarda, tal como recuerdan las disposiciones del sínodo toledano de 1480. Este les insta a abstenerse de toda obra servil y a que no fagan cosas de oficios ni de artificios ni se entrometan en labranças de pan e en labrar las tierras ni coger el pan, salvo con urgente necesidad e evidente causa de piedad, y aún en estos casos con licencia sacerdotal. La prohibición de trabajar les permitiría estar disponibles para cumplir con la obligación de reservar para servicio suyo e exercicio de obras espirituales el dia santo del domingo e las otras fiestas por la Santa Madre Iglesia instituidas $^{37}$. Ahora bien, estas obligaciones no siempre se cumplirían con el celo debido a tenor de las frecuentes reiteraciones de los cánones sinodales o, por ejemplo, de los estatutos de la catedral de Toledo. De hecho, una de las dignidades del cabildo, el vicario de la ciudad, tenía entre sus atribuciones la de imponer, con la ayuda de un fiscal, penas a los que trabaxaren los dias de fiesta como son los çapateros y tenderos que suelen tener las puertas abiertas y los basureros y molineros y aguadores y otros officios, tal como se señala en el estatuto que delimita las competencias de tal dignidad capitular ${ }^{38}$. Los curas, además, debían instar a los fieles a que estuviesen en la iglesia desde el principio hasta el final, callados y rezando, lo que no habla muy bien de la intensidad de su fervor religioso ${ }^{39}$.

Poco más indican esos textos sobre forma en que los fieles debían honrar esas fiestas, excepción hecha de la obligación que tenían una vez al año, por Pascua de Resurrección, de confesar y comulgar, tal como dispuso el

\footnotetext{
${ }^{35}$ Ladero 2004, pp. 29-31.

${ }^{36}$ Sánchez 1976, p. 198; García 2011, p. 551.

${ }^{37}$ Sánchez 1976, p. 306; García 2011, p. 637.

${ }^{38}$ Lop 2003, p.171.

${ }^{39}$ Muñoz 1993,pp. 460-461.
} 
sínodo de Toledo reunido por el arzobispo don Juan de Aragón en $1323^{40}$. Lo que sí tenemos es testimonios de la atracción que el ceremonial que adornaba algunas de estas celebraciones ejercía entre los fieles, que quedarían cautivados ante el boato desplegado, sobre todo, en los puntos fuertes del año litúrgico, como las citadas tres Pascuas, el Corpus Christi, San Juan Bautista o Santa María de Agosto. Aunque el interés por desarrollar estas fiestas con la mayor solemnidad posible sería común a los setenta templos asentados en nuestras ciudades, es evidente que no todos podrían, en función de su dotación económica y beneficial, aportar los "adornos" que la liturgia incorporaba al acto central con el que se conmemoraban las fiestas, esto es, la misa mayor. Me refiero a los cirios, incienso, vestidos litúrgicos, cruces, reliquias, sermones, cánticos y variadas melodías, que constituían un acompañamiento indispensable en todas estas festividades.

Ahí, sin duda, es la catedral primada la que ofrece una mayor información, ya que la profusión de detalles con la que la actividad litúrgica estaba descrita en los estatutos nos permite acercarnos bastante a esta realidad. La documentación muestra que los asistentes a las celebraciones procuraban rodearse de algunas "comodidades" materiales que les permitirían gozar lo más posible durante las muchas horas que duraban los servicios religiosos. Las actas capitulares constatan el descontento del cabildo ante la dificultad para escuchar con acatamiento, devoçion, sin escandalo y con onestidad los oficios que se decían en determinadas fiestas y solemnidades a causa de la costumbre de los laicos de personarse en el templo con mesas y comidas, de levantar sin permiso tablados y andamyos y de llevar consigo silla, vanco, almohada, estera, alhombra o tapiz alguno con la clara finalidad de ver las fiestas. Las intromisiones en el oficio divino que todo ello ocasionaba provocaron la prohibición absoluta por el cabildo de todas estas acciones, prohibiciones que afectarían a todos los fieles, independientemente de su posición social. Lo único a lo que accede la corporación es a proporcionar a cargo de la obra y durante los fríos inviernos esteras que esten entre los dos coros para que las mugeres oyan los sermones y los ofiçios divinos ${ }^{41}$.

Es difícil saber si esto es devoción o atracción por lo mucho que de escenificación y representación tiene los actos litúrgicos, ya que, como decía al principio, la línea que separa una de otra es singularmente tenue en muchas ocasiones. En todo caso, lo importante es que en ellos el pueblo tenía la ocasión de expresar sus sentimientos religiosos, su entusiasmo y su emoción. Lo mismo cabe decir de la importante participación popular que

${ }^{40}$ Sánchez 1976, pp.174-175; García 2011,p. 532.

${ }^{41}$ Lop 2003, pp. 357-358. 
concitaban las procesiones que, como prolongación de la liturgia desarrollada en el interior de los templos, recorrían las calles de las ciudades y constituían una de las expresiones más singulares de buena parte de las fiestas religiosas y de los modos locales de celebración. No se puede hablar de un único tipo de procesiones, ya que tanto las situaciones que las propiciaban, como sus características concretas fueron muy diversas. Algunas se convocaban con ocasión de acontecimientos extraordinarios, y otras venían marcadas en el calendario litúrgico; unas pocas se rodeaban de gran bullicio y algarabía, conformando un espectáculo difícil de igualar, mientras que la gran mayoría eran cortejos sencillos y de mayor recogimiento; unas estaban organizadas por las más altas instancias eclesiásticas y, en ocasiones, civiles de la ciudad; y otras eran convocadas desde instituciones de menor entidad o, cuando menos, con medios más limitados. Sea como fuere, lo importante es que todas ellas lograban reunir, además de al pueblo que asistía como espectador, a los diferentes sectores civiles y religiosos de la localidad que las albergaba.

Las seis ciudades que aquí nos ocupan son buen ejemplo de ello y, no solo en los días más solemnes y significados del año litúrgico, caso del Corpus Christi, fiesta urbana por excelencia y cuyas características y simbolismo son conocidas por todos ${ }^{42}$. Me refiero más bien a otras procesiones más modestas, organizadas por parroquias, monasterios, cofradías u hospitales en los días de sus advocaciones o en cumplimiento de los "votos" que los fieles habían establecido con diferentes santos protectores en demanda de amparo frente a situaciones adversas y con el que estaban obligados a cumplir ${ }^{43}$. Así, en Toledo están documentados nada menos que treinta y nueve de estos recorridos, todos los cuales, además de hacer estación en la catedral, se desplazaban por diferentes escenarios urbanos dentro y fuera de las murallas ${ }^{44}$. También Madrid o Guadalajara tienen constatada esa "movilidad ritual" por sus calles principales. En el primer caso se conoce la procesión que recorría el término parroquial de San Ginés en el día de San Luis, parece que con un origen votivo $^{45}$, y la que, por ejemplo, en 1426, trasladó las reliquias de san Isidro, santo protector de la villa, desde la iglesia de San Andrés a la de Santa María y al convento de Santo Domingo extramuros, solicitando su intercesión para que les librara de la sequía ${ }^{46}$. Por su parte, en Guadalajara, sabemos que desde 1364, cada 4 de mayo, desde la iglesia de Santiago a la de San Miguel se llevaban en andas las efigies de san Agustín y santa Mónica, en agradecimiento

\footnotetext{
${ }^{42}$ Fernández, Martínez 2002.

${ }^{43}$ Christian 1991, pp. 39-91.

${ }^{44}$ Fernández, Lop 2010.

${ }^{45}$ Muñoz 1993, p. 465.

${ }^{46}$ Andrés de 1986, p.155.
} 
por librarles de la peste ${ }^{47}$. El hecho de que todos estos actos litúrgicos tuvieran ese componente de oficialidad y fueran organizados por las autoridades eclesiásticas no impedía la devoción popular, ni la invalidaba en modo alguno.

\section{EL PATRONAZGO DE VÍRGENES Y SANTOS}

El patronazgo religioso es una de las formas de religiosidad que más contribuyeron a crear una conciencia de identidad en las comunidades locales, rurales o urbanas, amén de ser un claro exponente del arraigo que las devociones iban tomando en la sociedad. Esas comunidades van a encontrar en su fervor e identificación con uno o varios santos, y con sus imágenes y reliquias, no sólo unos intercesores directos con la divinidad, a los que poder acudir cuando las circunstancias les daban la espalda, sino también un potente elemento de cohesión interna y de distinción frente al exterior ${ }^{48}$. Estos protectores sagrados han llegado en muchos casos hasta nuestros días, como un claro indicador de la perdurabilidad que las devociones tienen en las mentalidades colectivas. En ello, claro, mucho tuvieron que ver los relatos y versiones escritas que, con mayor o menor verosimilitud, nos han transmitido las apariciones, milagros y circunstancias extraordinarias, que tanto han contribuido a popularizar y potenciar su culto.

Las ciudades del arzobispado de Toledo que aquí analizamos no permanecieron al margen de esta realidad devocional y reprodujeron con fórmulas similares a las de otros lugares esos estereotipos y modelos devocionales. Veamos cuáles eran.

\subsection{Las devociones marianas}

De todas las devociones, no hay duda de que la que se otorga a la Virgen en sus múltiples advocaciones fue la más arraigada de la Edad Media $^{49}$. Desde su eclosión en el siglo XIII, no es posible conocer la religiosidad medieval sin atender a su papel mediador. Los milagros que se atribuyen a su intercesión son constantes, lo que no hizo sino granjearle un puesto privilegiado en el fervor de los fieles. En los reinos hispanos el culto mariano corrió, además, paralelo al fenómeno de conquista y repoblación del territorio, de ahí

\footnotetext{
${ }^{47}$ Pradillo 2001, pp. 112-113.

${ }^{48}$ Martínez 2000, pp. 20-26.

${ }^{49}$ Iogna-Prat, Palazzo, Russo 1996; Torres 2002, 2016-2017
} 
el similar patrón que se reproduce por todas partes: partimos de imágenes de la Virgen que fueron ocultadas con motivo de la llegada de los musulmanes para evitar su profanación y que, tras la recuperación de estas tierras por los cristianos, son milagrosamente halladas, generalmente por pastores, niños o campesinos, en todo tipo de escenarios. La aparición suele ir acompañada de algún hecho extraordinario, lo que legitima el hallazgo y prueba la veracidad de la imagen. El lugar se santifica y, a partir de ahí, la devoción arraiga ${ }^{50}$. Estos hallazgos, si bien no constituyen una visión auténtica, sí tienen un cariz milagroso y se acompañan de signos sorprendentes - curaciones, luces y resplandores-, de ahí que calasen en la mentalidad popular y conformaran una perdurable tradición oral ${ }^{51}$.

Seis son las vírgenes que articulan desde antiguo la devoción en las ciudades del arzobispado y que a día de hoy siguen manteniendo ese patronazgo $^{52}$. De ellas, cuatro corresponden a la categoría de vírgenes soterradas, escondidas bajo tierra o bien ocultadas y halladas bajo un soto, en el interior de árboles, cuevas, grutas, fuentes, manantiales ${ }^{53}$. Es el caso de la toledana Virgen del Sagrario, hallada en un pozo de la catedral donde había sido escondida por los mozárabes durante la invasión. A esas aguas se le atribuyen curaciones milagrosas. Se dice que es la misma imagen que se veneraba en tiempo de San Ildefonso ${ }^{54}$. Similar advocación, Virgen del Prado, comparten Talavera y Ciudad Real, en atención a que su imagen se escondió bajo tierra, en un prado, y apareció milagrosamente tras la conquista ${ }^{55}$. Finalmente, la Virgen de Cortes, patrona de Alcaraz, apareció en el hueco del tronco de una encina. Su caso es especial porque su imagen no se venera en la ciudad, sino en una cercana ermita ${ }^{56}$.

Otras dos corresponden a la categoría de vírgenes emparedadas, que aparecen en el interior de paredes, murallas y torres. Es el caso de la Virgen de la Almudena, patrona de Madrid, cuyo origen, según la tradición, se remonta a los tiempos del apóstol Santiago, quien se decía la trajo a la península para dejarla depositada en la iglesia de Santa María. Los madrileños la ocultan a la llegada de los musulmanes, para redescubrirla en circunstancias milagrosas ya en tiempos de Alfonso VI: los fieles, que mantienen su recuerdo, quie-

\footnotetext{
${ }^{50}$ García, Sánchez 1988.

${ }^{51}$ Christian 1990, pp. 14-15.

${ }^{52}$ Virgen de Cortes (Albacete): 1 de mayo; Virgen del Prado (Talavera): 8 de agosto; Virgen del Sagrario (Toledo), Virgen del Prado (Ciudad Real): 15 de agosto; Virgen de la Antigua (Guadalajara): 8 de septiembre; Virgen de la Almudena (Madrid): 9 de noviembre.

${ }^{53}$ Puñal 1988, p. 293.

${ }^{54}$ Moreno 1995.

${ }^{55}$ Arganda 2001, pp. 349-350.

${ }^{56}$ Ayllón 2015, pp. 335-337; Pretel 2011; Torres 2013.
} 
ren hallarla, por lo que deciden hacer rogativas por toda la ciudad implorando una revelación; esa misma noche se desplomó un lienzo del muro y al irlo a reparar apareció la imagen ${ }^{57}$. También en el muro de una iglesia, en concreto la de Santo Tomé de Guadalajara, se encontró tras la conquista de la ciudad en tiempos de Alonso VI, la imagen de la Virgen de la Antigua, así denominada por ser la primera que recibió veneración en la ciudad ${ }^{58}$.

\subsection{Ildefonso e Isidro: dos modelos de santidad para Toledo y Madrid}

La identificación de las ciudades medievales con un santo patrón arranca desde la temprana Edad Media y, como el resto de iniciativas en materia devocional, cada una de ellas buscaba proyectar y reafirmar la propia imagen de comunidad. Las distintas urbes trataron de hallar sus propios intercesores, en un largo proceso en el que se sustituyen los más antiguos por otros que representan mejor las nuevas realidades del mundo urbano y que incluso fueron reclamados como tales por los vecinos y fieles de una localidad. Ello propició hallazgos fortuitos, traslados y falsificaciones de reliquias, indispensables para consagrar basílicas y altares y para el desarrollo de las muchas prácticas de piedad que, ligadas a ello, son tan ilustrativas de la espiritualidad medieval ${ }^{59}$.

También las ciudades que aquí nos ocupan recurrieron a la intercesión de varios santos y consagraron como tales a un variado elenco de personajes a los que acudían para implorar ayuda y cuyos valores y virtudes eran recordados en diferentes actos litúrgicos: los mártires Leocadia (Toledo) y Vicente, Sabina y Cristeta (Talavera), figuras tan señeras como san Agustín y su madre santa Mónica (Guadalajara) y, por descontado los dos casos a los que aquí me voy a referir, el de san Ildefonso y san Isidro, patrones respectivos de Toledo y Madrid. El hecho de que me centre en ellos se debe a que estamos ante dos figuras muy distintas, con poco en común por origen, extracción social, actividad y época en que viven, de ahí el interés por comparar los dos modelos de santidad que ambos representan.

Ildefonso es una figura altomedieval, uno de los cuatro componentes del episcopologio toledano visigodo que en el siglo VII alcanzaron la santidad: san Eladio (615-633), san Eugenio (646-657), el propio Ildefonso (657-

\footnotetext{
${ }^{57}$ Muñoz 1993, p. 528.

${ }^{58}$ Pradillo 2001.

${ }^{59}$ García de Cortázar 2006, pp. 294-295.
} 
667) y san Julián (680-690). Nuestro protagonista nacería hacia el 606 y viviría, por tanto, la época dorada de la Hispania visigoda y de su capital, la urbs regia de Toledo ${ }^{60}$. Nacido en el seno de una importante familia local, se formó en el prestigioso monasterio Agaliense, de donde fue abad, y participó en los concilios VIII, IX y, tal vez X, de Toledo. Es el propio rey Recesvinto quien lo designa para suceder a Eugenio en 657. En su pontificado escribió una serie de textos, especialmente el Libellus de virginitate sanctae Mariae contra tres infideles, auténtico hito en el desarrollo del culto a la Virgen en la Hispania visigoda y de gran difusión la Europa medieval ${ }^{61}$. Tras su muerte, dos obras nos ofrecen algunos detalles de su biografía: el breve Elogium que compuso san Julián, apenas diez años después de su muerte, y la Vita vel Gesta escrita por el también arzobispo Cixila (774-783), que, según dice, recoge de fuentes orales las dos principales tradiciones que se asocian al personaje: la aparición de la otra patrona local, santa Leocadia, mientras decía misa en su basílica, y la de la propia Virgen María, que desciende del cielo para sentarse en la cátedra episcopal e imponerle la casulla ${ }^{62}$.

Frente a este obispo e intelectual, la figura de Isidro no puede ser más distinta. Para empezar, es un laico, casado y padre de familia; su origen es humilde y su ocupación la de tantos otros hombres de su tiempo, el trabajo en el campo al servicio de otros. Ese tiempo también lo diferencia de Ildefonso, pues la vida de Isidro transcurre bastante después, a caballo de los siglos XI y XII, siendo difícil precisar las fechas concretas por la falta de documentación. La única e imprescindible fuente a través de la cual se construye su relato es el llamado Códice de Juan Diácono, escrito en la segunda mitad del siglo XIII. En él se refleja su vida de virtud, su permanente dedicación a la oración y la caridad que ejercía con los necesitados. No olvida tampoco recoger los milagros que le acompañaron en su día a día, como esos bueyes que le araban las tierras mientras él rezaba o los alimentos que se multiplicaban para poder alimentar a los pobres ${ }^{63}$.

Los diferentes modelos de santidad que ambos representan proyectan un tipo de devoción también distinta. La de Ildefonso más institucional que popular, puesto que el milagro mariano que protagoniza fue de inmediato asumido y oficializado por la diócesis, la catedral primada y la propia ciudad de Toledo, santificadas todas ellas por la aparición de la Virgen. De hecho, en la defensa de la primacía de Toledo frente a las reclamaciones de Santiago, Tarragona y Braga que hizo en el siglo XIII don Rodrigo Jiménez de Rada, ese

\footnotetext{
${ }^{60}$ Izquierdo 2007, pp. 143-159.

${ }^{61}$ Beltrán 1988, pp. 439-449; Gonzálvez 2010, p. 574; 2012.

${ }^{62}$ Fernández 2007, 2008.

${ }^{63}$ Muñoz 1990, 1993,pp. 552 y ss.; Sánchez, Puñal 2000.
} 
milagro sirvió como argumento, pues se dijo que la descensión de la Virgen a la Catedral de Toledo había ennoblecido más a Toledo que la sepultura de Santiago a Compostela ${ }^{64}$. Eso no significa que el pueblo no admirara ya en vida su figura, y que acudieran a escucharle, fascinado por su capacidad de comunicación y su elocuencia. A su muerte esa personalidad se agiganta y ya en el siglo VIII fue incluido en el calendario de santos toledanos sin necesidad de una declaración formal por la Iglesia, sino por consenso general de la comunidad católica de Toledo ${ }^{65}$. En cuanto a Isidro respondería más a las nuevas expresiones de piedad y espiritualidad, que se difundieron por las ciudades europeas desde la Plena Edad Media, en las que era clave la hominización de los destinatarios del culto y la oración ${ }^{66}$. Su devoción se gesta muy pronto, pues apenas treinta o cuarenta años después de su muerte ya hay noticia de ella. Tiene un matiz más popular, es un culto creado por los fieles, de radicación parroquial, que alcanzó el rango de patrón local y fue santo en la memoria del pueblo mucho antes de su canonización, que no llegó hasta $1622^{67}$.

Los hechos sobrenaturales que ambos viven en vida se trasladan a sus reliquias, pues los milagros continúan post mortem, una vez que se hallan sus restos y cobran fama sus propiedades taumatúrgicas ante enfermedades o catástrofes naturales. En el caso de Ildefonso, estos no se localizan hasta mediados del siglo XIII en la iglesia de San Pedro de Zamora, donde fueron llevados por fieles toledanos a la llegada de los musulmanes. Ya un siglo antes el propio Ildefonso había revelado a un pastor el lugar donde estaba enterrado, pero los clérigos zamoranos no le creyeron. Por eso no es hasta 1260 cuando unas obras descubren su sepulcro, que será trasladado al altar, donde será venerado $^{68}$. Por su parte, Isidro sería enterrado en el cementerio de la madrileña parroquia de San Andrés, pero apenas cuarenta años después se aparece a algunos fieles y manifiesta su deseo de reposar en un lugar más digno en el interior de la iglesia. Tras acceder el clero parroquial, se abre su sepulcro y aparece el cuerpo incorrupto del santo, que será trasladado al interior del templo ${ }^{69}$.

Lo cierto es que pese a ser diferentes en origen, ambas devociones se integraron en la vida local de sus respectivas ciudades. Se pondría su advocación a iglesias, ermitas y cofradías, y se haría procesión en su honor por diversos espacios urbanos. En cuanto a la conmemoración de su fiesta, la de San Ildefonso se celebraría el 23 de enero, día de su muerte, tal como estable-

\footnotetext{
${ }^{64}$ Gonzálvez 2010, pp. 576-577.

${ }^{65}$ Gonzálvez 2012, p. 21.

${ }^{66}$ García de Cortázar 2006, p. 284.

${ }^{67}$ García de la Borbolla 2006, pp. 123-124.

${ }^{68}$ Martínez 2000, pp. 28-30

${ }^{69}$ Muñoz 1990, pp. 186-192; 1993, pp. 571 y ss.
} 
ció el Concilio Provincial de Peñafiel de 1302, que la instituyó de obligado cumplimiento para la toda la provincia eclesiástica de Toledo ${ }^{70}$. En la ciudad de Toledo y, en concreto en la catedral, era una de las fiestas llamadas de seis capas, las más solemnes que se celebraban en el templo. La de San Isidro se oficializó el 15 de mayo, coincidiendo con su canonización a comienzos del siglo XVII, aunque de forma "oficiosa" estuvo instaurada y fue celebrada mucho antes por el pueblo.

\section{REFLEXIÓN FINAL}

Llegados a este punto, es momento de recapitular lo dicho sobre este conjunto de devociones y prácticas piadosas y sobre el papel que desempeñaban en las seis ciudades escogidas como marco de análisis. Vuelvo a señalar que lo que aquí se ha hecho solo ha sido un primer acercamiento al tema, habida cuenta de que la información tan desigual que existe sobre cada uno de esos lugares no permite ir más allá. No obstante, pese a ese carácter abierto, de "muestreo", que he querido dar a mi trabajo, sí es posible extraer algunas reflexiones.

La primera pone en evidencia algo obvio, el peso que los aspectos religiosos y devocionales ejercieron sobre la vida urbana del arzobispado de Toledo, en consonancia con lo que estaba ocurriendo en el resto de Occidente. Su papel fue clave para crear entre sus habitantes una conciencia colectiva de pertenencia, integración e identidad. El estrecho binomio que componen a lo largo de toda la etapa medieval Iglesia y ciudad encuentra sólidos anclajes precisamente en estas formas de expresión religiosa. Es verdad que lo más visible de esa unión es el imponente patrimonio artístico y monumental que nos ha legado, sin el cual no se entiende hoy el pasado de nuestras ciudades. Toledo con su catedral a la cabeza y con muchas de sus parroquias medievales aún en pie, es el caso más evidente, pero no el único a consignar. Ahora bien, junto a esos espacios sagrados hay otra huella no física, que atañe al patrimonio inmaterial e intangible que atesora toda comunidad y que también es memoria viva de cuántos aspectos hemos querido significar en estas páginas: las inquietudes, creencias, prácticas y expresiones de piedad que mostraban la devoción de los habitantes de las ciudades.

Constatado ese hecho, sería interesante establecer si esas devociones sirven realmente para determinar la jerarquización urbana, tal como apunta el título del presente trabajo. En el caso que nos ocupa, es evidente que Toledo,

${ }^{70}$ Sánchez 1978, p. 168. 
de la misma manera que estaba por encima del resto de lugares del arzobispado en el plano demográfico, económico o en relevancia política, también albergaba más templos y advocaciones, veía desfilar más procesiones, y congregaba a un mayor número de fieles en las celebraciones que conmemoraba. Ahora bien, ¿se correspondía ese mayor peso numérico con una clara influencia e interacción de sus devociones en las otras ciudades? A tenor de los datos disponibles hasta el momento cabe decir que no. Lo que se observa es que cada una de esas seis ciudades y villas desarrolló sus cultos propios, sin demasiada relación con lo que sucedía en las demás. Obviamente hay coincidencias, pero más porque corresponden a categorías similares de santos, prácticas y festividades, que por la puesta en marcha de una acción conjunta orquestada desde la sede de la archidiócesis. Es verdad que muy pocas ciudades podían competir en solemnidad litúrgica con Toledo y su catedral, que, además, ponía gran empeño en ser espejo en que las demás iglesias debían mirarse. No obstante, eso no implica, en modo alguno, una trasposición mimética de sus cultos y devociones.

Hay un aspecto interesante que puede ayudar a entender esta circunstancia y que tiene que ver con la enorme superficie del arzobispado, que se extendía de norte a sur, por los valles del Tajo y el Guadiana y, de oeste a este, desde Extremadura hasta la sierra albacetense de Alcaraz. Estamos ante una zona poco poblada desde antes incluso de la incorporación al dominio cristiano, incorporación que se hizo, además, en etapas bien distintas, que afectaron, lógicamente, a nuestras ciudades. Así, Toledo, Talavera, Madrid y Guadalajara lo harían en torno a 1085, Alcaraz más de un siglo después, en 1213, y Villa Real no se fundó hasta 1255, sucediendo a Calatrava, único enclave auténticamente urbano existente en el territorio manchego. Ello propiciará en cada una de ellas un diferente ritmo en cuanto a la restauración de la vida eclesiástica, que se hará extensivo a la implantación de cultos y devociones. Además, la repoblación de estos lugares se hizo con pobladores venidos de muy distintos puntos -mozárabes desterrados de Andalucía, gentes de Castilla y distintos puntos de la Meseta norte -, que trajeron consigo los usos devocionales de sus lugares de origen. De esta forma, cada zona, cada urbe funcionó de forma un tanto individual y autónoma, por lo que los parecidos entre ellas responden más a circunstancias que son "universales" y comunes a todo Occidente, que a la puesta en marcha de un plan establecido por la metrópoli toledana. Así se explica la poca presencia de una devoción local como la de san Ildefonso, a quien, por el contrario, sí se rindió culto en Zamora y su área de influencia dada la cercanía de sus reliquias.

Sí que se puede detectar esa interacción urbana a escala menor, entre las ciudades y sus tierras circundantes. Basten dos ejemplos. El culto local a santa Leocadia, patrona de Toledo, se extendió hasta Talavera, donde fue 
titular de una parroquia. Por su parte, san Isidro pronto sobrepasó el ámbito parroquial en el que nace y se extrapoló, no sólo a la ciudad, sino a la Tierra madrileña. Parece pues más fácil la extensión de estos cultos y devociones desde las ciudades a sus áreas más cercanas, que no al conjunto del arzobispado. Es verdad que desde Toledo los prelados dictan normas, instituyen fiestas y establecen prácticas de obligado cumplimiento por los clérigos y fieles sometidos a la jurisdicción arzobispal; pero, fuera de allí, hay un margen que permite a cada colectividad desarrollar sus propias formas y modelos.

Todas estas ideas no hacen sino mostrar la pertinencia de seguir avanzando en este tema, aquí brevemente esbozado. Para poder calibrar realmente si los cultos se expanden de una ciudad a otra, si hubo algún tipo de rivalidad o de colaboración y los mecanismos que articularon todo ello, sería necesario realizar una amplia búsqueda documental, que permitiera elaborar trabajos de base para cada uno de los lugares señalados. Además habría que abrir el abanico de temas a esos aspectos que aquí, por falta de espacio, hemos dejado a un lado, como las ermitas y cofradías, los rituales funerarios o los altares, imágenes y representaciones iconográficas que albergaba cada uno de los templos. Solo así, con mayores conocimientos, se podrá realizar un análisis comparativo, valorar el auténtico peso que el factor devocional tuvo en el fenómeno urbano y conocer la interacción de las ciudades de más entidad con las villas y enclaves rurales de su entorno. Las páginas precedentes creo que han dejado claro que estamos ante un tema por construir y en el que seguir avanzando en el futuro.

\section{BIBLIOGRAFÍA CITADA}

Andrés, Gregorio de (1986), Actas de la visita al arcedianazgo de Madrid en 1427, "Hispania Sacra" 38, pp. 153-245.

Arganda Martínez, Adolfo (2001), Historia de la Talavera cristiana. La Iglesia en Talavera (siglo I al XV), Talavera de la Reina, A. Arganda.

Asenjo González, María (2003), Demografía. El factor humano en las ciudades castellanas y portuguesas a fines de la Edad Media, en XXIX Semana de Estudios Medievales. Las sociedades urbanas en la España Medieval, Pamplona, Gobierno de Navarra, pp. 97-150.

Asenjo González, María (2013), Fiestas y celebraciones en las ciudades castellanas del siglo XV, "Edad Media. Revista de Historia" 14, pp. 5561.

Asenjo González, María (2016), Urban Identity in Castile in the $15^{\text {th }}$ Century, "Imago temporis. Medium Aevum" 10, pp. 291-312. 
Ayllón Gutiérrez, Carlos (2010), Estructura parroquial en el Sureste de Castilla a fines de la Edad Media, "Medievalismo" 20, pp. 173-202.

Ayllón Gutiérrez, Carlos (2015), Iglesia rural y sociedad en la Edad Media (Alcaraz y Señorio de Villena), Madrid, Sílex.

Barrio Barrio, Juan Antonio (coord.) (2009-2010), Espacios de identidad política urbana en la Península Ibérica, "Anales de la Universidad de Alicante. Historia Medieval" 16.

Beceiro Pita, Isabel (coord.) (2014), Poder, piedad y devoción. Castilla y su entorno, siglos XII-XV, Madrid, Sílex.

Beltrán Torreira, Federico Mario (1988), San Ildefonso de Toledo y el culto a la Virgen en la Iglesia hispano-visigoda: problemas históricos y doctrinales, en Devoción mariana y sociedad medieval, Ciudad Real, Instituto de Estudios Manchegos, pp. 439-449.

Campos y Fernández de Sevilla, Francisco Javier (1986), La mentalidad en Castilla la Nueva en el siglo XVI (Religión, economía y sociedad según las Relaciones Topográficas de Felipe II), San Lorenzo de El Escorial, Ediciones Escurialenses.

Christian, William A. (1990), Apariciones en Castilla y Cataluña (siglos XIVXVI), Madrid, Nerea.

Christian, William A. (1991), Religiosidad local en la España de Felipe II, Madrid, Nerea.

Díaz Ibáñez, Jorge (2002), Apuntes sobre la religiosidad del clero y los laicos en el obispado de Cuenca durante la Baja Edad Media, "Archivo Conquense" 5, pp. 41-74.

Fernández Collado, Ángel (2007), La descensión de la Virgen María a Toledo y su manifestación en la catedral primada, en Hispania Gothorum. San Ildefonso y el reino visigodo de Toledo, Toledo, Empresa Pública Don Quijote, pp. 337-352.

Fernández Collado, Ángel (2008), La Capilla de la Descensión y la entrega de la casulla a San Ildefonso, en Vizuete, José Carlos; Martín, Julio (coords.), Sacra loca toletana. Los espacios sagrados en Toledo, Cuenca, Universidad de Castilla-La Mancha, pp. 263-287.

Fernández Collado, Ángel; Lop Otín, María José (2010), Las procesiones de Toledo en la Edad Moderna: punto de encuentro de la catedral y las instituciones religiosas de la ciudad, "Memoria Ecclesiae" 34, pp. 321-349.

Fernández Juárez, Gerardo; Martínez Gil, Fernando (coords.) (2002), La Fiesta del Corpus Christi, Cuenca, Universidad de Castilla-La Mancha.

García de la Borbolla, Ángeles (2006), El culto a los santos en el marco espacial urbano de la Castilla del siglo XIII, en González Jiménez, 
Manuel (ed.), El mundo urbano en la Castilla del siglo XIII, Sevilla, Fundación El Monte, vol. II, pp. 121-128.

García de Cortázar y Ruiz de Aguirre, José Ángel (2006), La Civitas Dei: la ciudad como centro de vida religiosa en el siglo XIII en González Jiménez, Manuel (ed.), El mundo urbano en la Castilla del siglo XIII, Sevilla, Fundación El Monte, vol. I, pp. 275-301.

García y García, Antonio (dir.) (2011), Synodicon Hispanum, vol. X: Cuenca y Toledo, Madrid, Biblioteca de autores cristianos, pp. 519-829.

García Martín, Pedro; Sánchez Benito, José María (1988), Pastoris, infans et rustici: testigos de apariciones marianas en Castilla, en Devoción mariana y sociedad medieval, Ciudad Real, Instituto de Estudios Manchegos, pp. 155-174.

Gonzálvez Ruiz, Ramón (1978), El arcediano Joffré de Loaysa y las parroquias urbanas de Toledo en 1300, en Historia Mozárabe. I Congreso Internacional de Estudios Mozárabes, Toledo, Instituto de Estudios Visigótico-Mozárabes de San Eugenio, pp. 91-148.

Gonzálvez Ruiz, Ramón (2010) La devoción mariana, en La Catedral primada de Toledo. Dieciocho siglos de Historia, Burgos, Promecal, pp. 570-579.

Gonzálvez Ruiz, Ramón (2012), San Ildefonso de Toledo y su obra. De la virginidad de Santa María, en Sancti Ildefonsi toletani eposicopi. De virginitate Sanctae Mariae, Toledo, Instituto Teológico San Ildefonso, pp. 21-103.

Igual Luis, David (2002), La Baja Edad Media (siglos XIV-XV), en Izquierdo Benito, Ricardo (dir), Castilla-La Mancha Medieval, Ciudad Real, Manifesta, pp. 169-239.

Iogna-Prat, Dominique; Palazzo, Eric; Russo, Daniel (1996), Marie. Le culte de la Vierge dans la société médiévale, París, Beauchesne.

Izquierdo Benito, Ricardo (2006), Rasgos urbanísticos de las ciudades del Reino de Toledo en el siglo XIII, en González Jiménez, Manuel (ed.), El mundo urbano en la Castilla del siglo XIII, Sevilla, Fundación El Monte, vol. I, pp.123-144.

Izquierdo Benito, Ricardo (2007), La urbs regia, en Hispania Gothorum. San Ildefonso y el reino visigodo de Toledo, Toledo, Empresa pública Don Quijote, pp. 143-159.

Izquierdo Benito, Ricardo (2016), Los lugares de culto en Toledo en los siglos medievales. Iglesias, mezquitas, sinagogas, Madrid, Sociedad Española de Estudios Medievales.

Jara Fuente, José Antonio (coord.) (2013), Ante su identidad. La ciudad hispánica en la Baja Edad Media, Cuenca, Universidad de Castilla-La Mancha. 
Ladero Quesada, Miguel Ángel; Sánchez Herrero, José (1991), Iglesia y Ciudades, en Las Ciudades Andaluzas (siglos XIII-XVI). Actas del VI Coloquio Internacional de Historia Medieval de Andalucía, Málaga, Universidad de Málaga, pp. 227-264.

Ladero Quesada Miguel Ángel (2004), La fiesta en la cultura medieval, Barcelona, Areté.

Ladero Quesada Miguel Ángel (2010), Ciudades de la España Medieval. Introducción a su estudio, Madrid, Dykinson.

Layna Serrano, Francisco (1942), Historia de Guadalajara y sus Mendoza en los siglos XV y XVI, vol. I, Madrid, Aldus.

Lóbrichon, Guy (1994), La religion des laïcs en Occident, $X I^{e}-X V^{e}$ siècles, París, Hachette.

Lop Otín, María José (2003), El cabildo catedralicio de Toledo en el siglo XV: aspectos institucionales y sociológicos, Madrid, Fundación Ramón Areces.

Lop Otín, María José (2012), Parroquias y práctica sacramental en Toledo a fines de la Edad Media, en Mundos medievales: espacios, sociedades y poder. Homenaje al profesor José Ángel García de Cortázar y Ruiz de Aguirre, Santander, Universidad de Cantabria, vol. II, pp. 1523-1536.

Lop Otín, María José (2014), Iglesia y vida urbana. Las ciudades del arzobispado de Toledo a fines del Medievo, "Edad Media. Revista de Historia" 15, pp. 135-154.

Martínez Gil, Fernando (2000), Religión e identidad urbana en el Arzobispado de Toledo (siglos XVI-XVII), en Vizuete, José Carlos; Martínez-Burgos, Palma (coords.), Religiosidad popular y modelos de identidad en España y América, Cuenca, Universidad de Castilla-La Mancha, pp. 15-57.

Montero Málaga, Alicia Inés (2012), Identidad e identidades. La identidad política en la historia urbana medieval. Balance historiográfico y perspectivas de análisis, "Estudios Medievales Hispánicos" 1, pp. 121-142.

Moreno Nieto, Luis (1995), La reina de Toledo: historia de la Virgen del Sagrario, Toledo, Imprenta Serrano.

Muñoz Fernández, Ángela (1990), Creación popular en la intervención clerical en la modulación de la tradición hagiográfica de San Isidro, en Miguel, Juan Carlos de (coord.), El Madrid medieval: sus tierras y sus hombres, Madrid, Asociación Cultural Al-Mudayna, pp. 151-175. 
Muñoz Fernández, Ángela (1993), Madrid en la Edad Media. Análisis de una comunidad urbana y su entorno rural en sus relaciones con el hecho religioso, Madrid, Universidad Complutense (tesis doctoral).

Muñoz Fernández, Ángela (2002), Las redes primarias de lo urbano (a propósito de los espacios parroquiales del Madrid medieval, "Revista de Filología Románica" anejo III, pp. 65-80.

Narbona Vizcaíno, Rafael (2017), La ciudad y la fiesta: cultura de la representación en la sociedad medieval, Madrid, Síntesis.

Pérez González, Silvia María (2005), Los laicos en la Sevilla bajomedieval. Sus devociones y cofradías, Huelva, Universidad de Huelva.

Pradillo Esteban, Pedro José (2001), Nuestra Señora de la Antigua. Devoción y Patronazgo en Guadalajara, "Cuadernos de etnología de Guadalajara" 32-33, pp. 111-142.

Pretel Marín, Aurelio (2000), Iglesia, religión y religiosidad en la Baja Edad Media albacetense, "Al-Basit" 44, pp. 45-109.

Pretel Marín, Aurelio (2011), Orígenes históricos del santuario y el culto de la Virgen de Cortes, en Nuestra señora de Cortes: los senderos de la $f e$, Albacete, Diputación Provincial.

Puñal Fernández, Tomás (1988), Invenciones marianas en el ámbito castellano-manchego: un estudio tipológico durante la Reconquista, en Devoción mariana y sociedad medieval, Ciudad Real, Instituto de Estudios Manchegos, pp. 291-305.

Puñal Fernández, Tomás; Sánchez Benito, José María (2000), San Isidro de Madrid: un trabajador universal, Madrid, Ediciones La Librería.

Sánchez Herrero, José (1976), Concilios provinciales y sínodos toledanos de los siglos XIV y XV. La religiosidad cristiana del clero y del pueblo, La Laguna, Universidad de La Laguna

Sánchez Herrero, José (1978), Las Diócesis del Reino de León. Siglos XIV y $X V$, León, Centro de Estudios e Institución "San Isidoro".

Sánchez Herrero, José (1982), La Iglesia andaluza en la Baja Edad Media, Siglos XIII al XV, en Actas I Coloquio de Historia de Andalucía. Andalucía Medieval, Córdoba, Caja de Ahorros de Córdoba, pp. 265-330.

Stabel, Peter (2000), Urbanization and its Consequences: the Urban Region in Late Medieval Flanders, en Ainsworth, Peter F.; Scott, Tom (eds.), Regions and Landscapes: Reality and Imagination in Late Medieval and Early Modern Europe, Oxford, Peter Lang, pp. 177-203.

Torres Jiménez, Raquel (2002), Formas de organización y práctica religiosa en Castilla la Nueva. Siglos XIII-XVI, Madrid, Universidad Complutense (tesis doctoral). 
Torres Jiménez, Raquel (2006a), El Libro de Beneficios del Arzobispado de Toledo (1501) y la Geografía Archidiocesana, "Memoria Ecclesiae" 28, pp. 473-501.

Torres Jiménez, Raquel (2006b), Notas para una reflexión sobre el Cristocentrismo y la devoción medieval a la Pasión y para su estudio en el medio rural castellano, "Hispania Sacra" 58, pp. 449-487.

Torres Jiménez, Raquel (2013), Ermitas y religiosidad popular: el santurario de Cortes, en Alcaraz, del Islam al concejo castellano, Alcaraz, Ayuntamiento de Alcaraz - Albacete, Instituto de Estudios Albacetenses, pp. 187-214.

Torres Jiménez, Raquel (2016-2017), La devoción mariana en el marco de la religiosidad del siglo XIII, "Alcanate" 10, pp. 23-59.

Val Valdivieso, Isabel del (2006), La identidad urbana al final de la Edad Media, "Anales de Historia Medieval de la Europa Atlántica" 1, pp. 5-28.

Vauchez, André (1994), La sainteté en Occident aux derniers siècles du Moyen Âge. D'après les procès de canonisation et les documents hagiographiques, Roma, École française de Rome.

Vauchez, André (dir.) (1995), La réligion civique a l'epoque médiévale et moderne, París, École française de Rome.

Villegas Díaz, Luis Rafael (1981), Ciudad Real en la Edad Media. La ciudad y sus hombres (1255-1500), Ciudad Real, Diputación Provincial.

Fecha de recepción del artículo: octubre 2017

Fecha de aceptación y versión final: marzo 2018 